\title{
ON THE FRESHIVATER SHELLS OF TASMANIA.
}

\author{
By Rev. J. E. Tennison Wooms, F.G.S., F.L.S.
}

[Read 9th August, 1875.]

Introduction. - No attempt has yet been made to arrange the freshwater shells of T'asmania. 'The land shells bave been - carefully catalogued by Mr. Legrand, so that little remains to be desired in that department of our island fiuna. The marine sliells have reeeived much attention from most eminent naturalists, though a list carefully eritieised, with a well arranged aceount of the bibliography is much wanted. But the freshwater shells have been almost entirely neglected. There have been one or two descriptions of Physi in Reeve, and one or two other notices of speeies scattered through various scientific nublications, but the majority of the sliells here described are new to science. 'This comparative neglect has one advantage, which is, that the whole can be done without a troublesome synonomy. There are other advantages in describing species in their native country. Mistakes as to the habitat are thus avoided by the examination of large collections, all the variations to which any species is subject can be observed, and details which in isolated specimens might be regarded as of specific value are rightly estimated, and the unnecessary multiplication of species obviated. For this reason $I$ am sure that it is no real gain to science to send one or two natural history specimens to scientific men at home no matter how eminent they may be. In this way, a hopeless confusion of names and habitats arises, no accurate knowledge is gained, and science is, in fitet, really retarded. I say this because in the very subject I am now writing upon, I find in various eminent seientific works descriptions of $\Lambda$ ustralian freshwater shells, which I havo very little doubt were derived from Tasmania; and, further, I also find shells described as Tasmanian, whieh the most careful and painstaking collectors assure me have never been found in this island. Such instances I will note as I proceed.

The first faet that strikes us in the examination of the fresh water fauna of Tasmania is its perfect distinetuess from that of Australia. The latter is well marked, and there is the greatest distinctness hetween shells gathered in different parts of the continent. But with this fact there is another still more remarkable, that one of the Tasmanian Physæ, and that the most common seems searcely to be distinguished from the common Plyysa fontinatis of Europe, and it is found in places which preelude the supposition of its having been introduced. Moreover the facies or general charaeter of our freshwater 
shells is not Austriilian, which certininy is most singular', considering that the geographical relations of the two places are so elose. 'These ficts, howerer, are quite in keeping with the teachings of both the zoology and geology of Tasmania, namely, that the island lias been separated from the continent in very remote periods of the earth's history, perhapg since the close of the mesozoic.

Secondly, we find in the freshwater shells of Tasmania a singulinly restricted habitat for some species, and an unaccountably capricious distribution for others. Thus some species are only found in small inland lakes, and others are found in one restricted habitat, and then strangely reappear at other and remote parts of the island, while between the two localities there scems to be no present communication. Erery species, too, which has a wide range has a local variety. It would seem from these facts that the present plysical features of Tasmania have undergone little change in recent times, but the ontpouring of lavas, ete., in tertiary times, of which there is such evidence, has altered some of the inland characters, and so divided districts which may have been formerly united in their freshwater streams. This, however, is merely a supposition, which is only one of many which may be offered in explanation of the phenomena.

There are in all 32 species of freshwater known shells in Tasmania, that is to say, 28 unitalves and 4 bivalves; the proportion of bivalves to univalves for Britain is 29 to 9 . The Tismanian species are distributed in the following genera:Physa, 12 ; Limnea, 4; Bythinia, 7; Ancylus, 2; Pomiatopsis, 1; Planorbis, 1 ; Assiminea, 1. The latter is a very doubtfully referred to freshwater, being usually found only in brackisla streams. Still, as it seems to live in streams where the tidal influence of the salt water is scarcely felt, I must place the one Tusinanian species amongst the list of our freshwater fauna.

Of the genera, Plyssa is the largest in number, and this is the case also in Australia, where it takes the place occupicd by Limnea elsewhere. But the Australian species are generally rery globose with short spires or with a peeuliar elongation of the penultimate whorl, with a deeply impressed suture, and these features are not marked in the Tasmanian species. Their form rather approximates to the European and American types. The only exception is in P. citiala, which has a short. spire, and in the Bruni Island variety a globose habit. 'Those from Lake Dulverton are not globose. This species is also remirkiable for being elothed with long reddish hairs in its young state, a feature not scen in any other of its congeners except one from Indiat. It is very strange that this species is ouly found in Like Dulverton and Bruni Island, places more 
than eighty miles apart, and separated by an arm of the sea. In Lake Dulverton is found $P$. mamillata, which is also found in Bruni Island. I may here remark that a variety of the latter exactly corresponding with Sowerby's $P$. attenuata is found in the same lake, and though described as coming from Australia, Mr. W. Legrand assures me it came from I ake Dulverton, as it was sent to Mr. Sowerby from Tasmania by $\mathrm{Mr}$. Legrand. Under these circumstances, the species and name should be suppressed, but the matter is one for Australian naturalists. The common Physa of Tasmania I have named $P$. tasmanica. It varies very much according to the place in which it is found, and is closely allied to $P$. fontinalis of Europe. The number of Physas (12) for such a small island is very large, and it may be that some of the species will yet need reduction, yet it must be remembered that Tasmania is an extremely mountainous country. The ridges acting as complete barriers between different parts of the island.

The genus Bythinia contains species which may possibly need further reduction. Some authors have referred those species, of which the Tasmanian creeks, etc., are so full, to the genus Paludestrina. Under the head of that genus I have given my reasons for classing then as I have done. The partly calcareous operculum appears to me, in the absence of the animal, decisive of the point. Two species of Paludestrina have been described by Mr. Brazier as from Tasmania in the Zoological Society's proceedings, but I have never been able to find any collector who has seen them. I therefore conclude there is some mistake in the habitat. Nevertheless I have included them in the list, hoping that future investigas tions may throw some light on the point.

The four species of Limnea do not call for any remark except that they are local and very distinct from any European or Australian congeners.

The two species of Ancylus are very remarkable, in fact, Tasmania can boast of the largest and finest species of Ancylus known, being so distinct from every other species, that at one time it was proposed to erect a separate genus for its reception. The other species in no way resembles it, being small and inconspicuous.

The other genera have nothing peculiar about them. They are the representatives of European species in our streams. It is said that our Pomiatopsis is found in Australia, but as there it is claimed as a Blanfordia, the indentification is doubtful.

It is remarkable that there is only one Unio in Tasmania, and that is entirely restricted to rivers emptying themselves on the north side of the island. 
Altogether the fresh water shells of Tasmania present a novel and peculiar character which, when carefully studied, mily help to explain much of the distinctive zoology and geology of the island. So far as my observations go, its results seem more adverse than favourable to the Darwinian hypothesis, but the nature of this paper prevents my stating at any length the reasons which incline one to this opinion.

\section{UNIVALVES. ANCYLUS. GeofrroY, 1767.}

(Traite des coquilles de Paris par Etienne Louis Geoffroy, Paris, 1767.)

Testa tcnuis, oblique conica, apice acuto, posterius inflexo, apertura ovali; marginibus simplicissimis.

Shell thin, obliquely conical, apex acute, posteriorly inflated, aperture oral with quite simple margins.

These freshwater limpets are air breathers, and not nume. rous in species. They are found, says Mons. Bourguignat (who has made the genus the subject of a most elaborate paper in the Zool. Soc. Proceed. for 1853 p. 77) in all the great divisions of the world, but the section Velletia has hitherto only been found in Europe. About 50 species are known.

Ancrlus cumingianus, Bourguignat (loc. cit.) A. testa antice gibboso-convexa, postice concava, apice recurvo, contorto, ad marginem aperturce lateralem dextrorsus dejecto, ac duos anfractos prcebente; anfractibus depressionem apicalem convexitate penultimi obtegentibus. Testa parum diaphana, levi vel striata, presertim ad aperturam; anfractibnes apicis scepissimi rugoso-radiatis ; epidermide supra cornea ırl virescente, intus albida; apertura subangulato-rotundata.

Shell gibbosely convex anteriorly, posteriorly concave, apex recurved, twisted and dextrally turned down to the lateral margin of the aperture, so as to make two whorls; whorls covering the apicial depression by the convexity of the penultimate. Shell slightly diaphanous, smooth or striate about the aperture, the apicial whorls very often rugosely radiate, epidermis grcenish or horny above, white within; aperture subangulately rounded. Iiength $6-7$. Breadth, $5-5 \frac{1}{2}$. Alt., $2 \frac{1}{2}-3$ mill. But specimens have been placed in my hands by $\mathrm{Mr}$. Legrand of neariy double this measurement.

'This species is truly the finest Ancylus known, having no congeners in any way approaching it. Latia neritoides of New Zealand may be compared with it in some respects. Its peculiar fertures are its size, the excessive deviation of the apex, its peculiar spiral apex, its mode of growth and the form of its aperture. These separate it completely from all species hitberto knowll. Habitat, in streams between New Norfolk and Hamilton. The large ones referred to from a small 
stream running into the Derwent near Dumrobin.- $R$. Mraddock.

Ancrlus tasmanicus. n.s. A. testa parva, oblongo-ovata, diaphana, cornea, concentrico striata, et subtillisime rugoso-radiata, epidermide nigro plus minusve induta ct maculata, apice obtuso, postico ; apertura postice subatenuata.

Shell small, ovate, diaphanous horny, concentrically striate and very faintly rugosely radiate, more or less covered and spotted with a black epidermis, apex obtuse, posterior aperture subattenuate posteriorly. Long., $3-3 \frac{1}{2}$. Lat., $1 \frac{1}{2}-2$. Alt., $1 \frac{1}{2}-2$.

Common near Hobart Town in streams, on stems of watercress (Nasturtiun officinale.

\section{LIMNEA. LAMARCK, 1799.}

Testa oblonga, interdum turrita; spira exserta, apertura integra, longitudinalis. Labrum acutum, infernć ad sinistram revertens et ascendens, in columellam rersus aperturam decurrit, plicamque obliquam mentitur. Operculum nullum. Hist. Nat. des Anim. s. Verteb. 2 edit par Deshayes et Milne Elwards. Paris, 1838.

Shell obloug, sometimes turretted, spire exsert. Aperture entire, longitudinal. Outer lip acute returning to the left, and ascending decurrent with the columella towards the aperture making a false oblique plait. No operculum.

The Limnex aro world-wide in their distribution, and inhabit ponds, lakes, and running water. The species have a wide distribution, so that it is difficult to distinguish between those found in America and Europe. Sowerby says that the Australian species have generally an inflated form, while Lovell Reeve (Land and Freshw. Moll of Brit. p. 155) says, "InIndia, neighbourhood of Calcutta, the shell is cylindrically oblong. In Malayan Islands and Punjaub districts of India it is of a peculiarly silvery horny substance, marked with opaque white brown streaks. Western Asia, north of the Himalayas, over the whole of Europe, extending to Greenland, and over all the United States, the Limnex produce a dull horny malleated shell. The inland waters of Central America and Australia have few Limneæ. They are chiefly inhabited by Physæ.

1. Linnea TASManica n.s. P.testa temui,pellucida, eleganter pyramidata, corneo-fulva; spira elevata, acuminata, apertura lungitudine, paulo superanti; anfractibus (5-8) obliquis; ultimo anfracto inflato; apertura late ovata; labio externo tenuissimo, fragilis; labio interno subexpanso, plica inconspicua, colrcmella alba, vix contorta.

P. shell thin, pellucid, elegantly pyramidal, horny fulvous; spire elevated acuminated, aperture little larger than the 
spire, whorls 5 to 8 , oblique, last whorl inflated, aperture widely ovate; outer lip extremely thin, fragile; inner lip somewhat expanded, columella fold inconspicuous; columella white, scarcely twisted. Long. 25. Lat. 12. Apert. 15 mill. But this is a large size.

Habitat. -Ererywhere in South Tasmania about Hobart. This shell is very like Limnac stagnalis, Linn, but the spire is not so attenuated, the aperture not nearly so expanded, the columella fold is inconspicuous, the columella white, and the shell much smaller and thinner. It also comes near some American species.

2. Limsen Hutöexsis. L. testa temuisima, pellucida, nitida, ventricosa, pallide comea, rectiuscula, spira brevi, acuta; anfractibus (4) productis, labio externo tenuissimo, ucuto ; labio intemo expunso; plica contortu, columelle arcuato.

Shell very thin, pellucid, shining, ventricose, pale horny, rather straight, spire short, acute, whorls 4, penultimate whorl rounded; last whorl large, concave behind the columella, aperture ovate, produced; outer lip very thin, acute; inner lip expanded, fold twisted, columella arched. Long. 8. Lat. $4 \frac{1}{2}$. A pert. 5 mill.

Habitat, River Huon, upper part, Craycroft River, \&c. This very interesting species comes some what near $L$. pinguis of America.

3. Linnja hobartonensis, n.s. L. testa ventricosa, subumbïicata, obliqua, pallide-cornea, spira brevi, anfiactibus 4, duobus apicalibies parvis, rotundis, penultimo majusculo, ultimo inflato; post columellam concuro, apertura obliqua, pyriformi, antice oblique expansa; labio externo tenui; labio interno vix expanso, plica quasi olsoleta.

L. shell ventricose, subumbilicate, oblique, horny, spire short, whorls four, the two apicial ones small, rounded, the penultimate somewhat larger, the last inflated; concave behind, the columellar aperture pyriform, obliquely expanded in front, outer lip thin, inner lip expanded, columellar plait almost obsolete. Long. 11. Lat. 8. Aperture 9 mill.

Habitat, very common about waterworks near Hobarton. Closely allied to preceding, but the spire is more conspicuous and the shell oblique, more solid, and altogether larger.

4. Lims.lia LaUderstonensis n.s. L. testu temussima, pellucida, alba, nitidissima, rentricosa, restinscula; spira breri, acute; anfractibus 4, uitino magno, post columellam concaxo; apertura pyriformi; labio esterno expanso, acuto, fragilis ; columella arcuata, plice inconspicue.

Shell very thin, pellucid, white, very shiny, ventricose, somewhat straight, spire short, acute, whorls four, last large, concave behind the columella; aperture pyriform; outer lip 
expanded, acute, fragile ; columella arched, plait inconspicuous. Long. 15. Lat. 9. Aperture 11 mill.

Habitat, Creek near Launceston. While in habit this shell much resembles the two preceding it is larger and of shining white or silvery lustre. I also think that there are signs of a band circling the shell formed by two parallel lines.

\section{PHYSA.}

Genus Physa Draparnaud. IIist. Nat. des Moll. de., de la France, 1805.

Testa fuviatilis, cornea, tenuis, spiralis, sinistrorsa, plerumque ovato-acuminata; lubio externo acuto, simplici; labio interno expanso, cum columelle continuo; columella contortu, uniplicata, operculum nullum.

Shell fluviatile, horny, thin, spiral, sinistral, generally ovate, acuminated; outer lip expanded, continuous with the columella; columella tortuous, singly-plaited. No operculum.

The Physæ may be considered sinistral or reversed Limneadæ. They are most numerous in warm countries, but are found in Britain. The usual species are found in Europe and South Africa, and they prefer running streams.

1. P. APERTA. P. testa parva, brevi, ovata, inflata, epirlermide olivace-fusca induta; spira brevissima, anfiactibus duobus, ultimo inflato, superne sub-gibboso; apertura magna, lata, intus sub corrulea, columella contorta, plica prominula.

Shell small, short, ovate, inflated, covered with an olive brown epidermis; spire very short, with two whorls, last whorl inflated, rather gibbous above: aperture large, broad, bluish within, columella tortuous, fold rather prominent. Sowerby, in Reeve's Icon. Plate xi., figs 88, a b.

Habitat, creeks between Hamilton and New Norfolk, Tasmania.

2. P. eburnea. P. testa gracili, obliqua, subfusiformi, polita, alba, fulvescenti, semipellncida; spira acuminate, quam apertura longiori; anfractibus obliquis, declivibus, attenuatis; apertura brevinscula, subauriformi, intus fusco vubescenti; columella contorta, alba medio interdum incrassata.

Shell slender, oblique, rather fusiform, polished white fawn, semipellucid; spire acuminated, longer than the aperture, whorls oblique, sloped, attenuated; rather short, subauriform, reddish brown within, columella tortuous, white, sometimes thickened in the middle.

Sowerby, in Reeve's Icon. Pl. xi., figs 89 a. b.

Habitat, creeks near Launceston.

S. Physa mamblata. $P$. testa elongata, fusca, antice subc $x$ pansa; spira quam upertura breviuscula; anfractibus apicalibus 
minutis, acuminatis, antepemultimo inflato gibboso, penultimo inflato, yibhoso, etongato!; niltimo anfractu attemuato, subcylindrico, antice oblique subcrpanso; apertura oblonga, intus subviolacea, columella temii, conturte, plica elcruta.

Shell elongated, brown, anteriorly somewhat expanded, spire a little shorter than aperture, spiral whorls minute, acuminated, antepenultimate inflated, gibbous, penultimate inflated; last whorl attenuated subcylindrical, anteriorly obliquely rather expanded, aperture oblong, rather violet within, colnmella thin, tortuous plait elevated. Length 27 ; breadth at aperture 7 mill.

Sowerby, in Reeve's Icon. Pl. xi., fig 90.

Habitat, Lake Dulverton.

4. P. ximina. Soverby. P. testa parva, subfusiformi, pallide fulna, levigata, oblique; spiru brerinescula, anfrae. apicalibnes acuminatis, perris, ponneltimo inflato ; ultimo cinfrec. ovato, tumidiusculo, anticc rotunduto; apertura orato, columelle contorta, plica inconspicue.

P. shell small, subfusiform, pale, fulvous, smootl, oblique ; spire rather short, spiral whorls acuminated, small, the penultimate inflated; last whorl ovate, rather tumid, anteriorly rounded; aperture ovate, columella tortuous, plait inconspicuous. Length from 6 to 9 , breadth from 3 to $4 \frac{1}{2}$ mill.

Reeres' Icon. Pl. xii., figs 98 a. b.

Habitat, in creeks S. E. Tasmania.

5. P. BR Uniensis. Souverby. P. testa parva, oblonga, anguesta, pellacida, nitenti; spira brevinscula, anfrac. 3, aistinetis, prope suturum gibbosis, ultimo oblongo ; apertura angustiuscula, columella tenuissima, plica, inconspicua.

P. shell, small, oblong, narrow, pellucid, shining; spire rather short, whorls three, distinct, gibbous near the suture, the last oblong; aperture, rather narrow, columella very thin, plait inconspicuous.

Habitat, Bruni Island. Reeve Icon., pl xii., fig. 99.

6. Pursa vandfeuenexsis. Sow. P. testa solida, subquadrata, fumoso-comea; spiru brevi, anfrac. pancis, subangulatis; ultimo anfractu oblongo, prope suturam angulato; apcrtura subqualrute, intus obsenè purpurasccuti; lubio externo untice cxpanso, columella contorta, recurvu.

P. shell solid, rather square, smoky horn color ; spire short, whorls few, subangular; last whorl oblong, angular near the suture; aperture squarish, dull purplish within, outer lip anteriorly expanded, columella tortuous, turned backward. Length 17. Breadth 8.

Habitat, northern Tasmania. I have never seen this species.

Reeve's Icon. Pl. viii. fig. 57.

Sowerby remarks of this species that its oblong, square, 
angular form is unusual in the genus, but that this only appears strongly in mature specimens.

7. Physa huonensis, n. s. P. testa, parva ovato-fusiformi, pellucida, nitente cornea; spira subproducta; anfi. (5), apicalibus acuminutis, parvis, ponultino longinesculo; apertura producta, auriformis; columella temu, arcuata, plica vix visibilis.

P. shell small, ovately fusiform, pellucid, shining, horny; spire sub-produced; whorls (5) the spiral acuminated, small, penultimate somewhat long, aperture produced, auriform; columellia thin, arched, fold scarcely visible. Long. 8, Lat. 3 . Aperture, 4 mill.

This shell is very distinct from $P$. bruniensis being larger and having the aperture regularly produced, but it has much the same luabit.

Halitat, Huon River, near Victoria. Legrand.

8. Physa. Legrandi. n.s. P. testu fusiformi, acuminata, tenuiter striata, subpellecida, pallide fulva, in partilnes fusca ; spira producta, attenuata, apice acuminato; anfrac (6) olliquis, attenuatis; ultimo anfrectu ublongo; apertura producta, auriformis, columella ascuata, plicu conspicua.

P. shell fusiform, acuminated, finely striated; sub-pellucid, pale brown, dusky in parts; spire produced, attenuated; apex acuminated, whorls 6 , oblique, attenuated, last oblong; ajerture produced, auriform, columella arched, plait conspicuous. Length 15 , breadth 7 mill.

This shell, which may be a large variety of the next species, las the acnminate oblique habit, which may be said to be the typical form of so many Australian and Tasmanian species.

Habitat, creeks Cambridge, near Richmond, Tasmauia.

9. Physa tasuanica, n.s., P. testa ovata, temui, nitenti, pcllucida, pallide fulvu, rufa, fusco-srebviridi, olivacea vel fusco-comea, palliele lutea et subulbu: spira brevi, acuminata; anfractilnes (5) declivis; apcrtura obliqua ; columello alba, tenui, contorta, plica subconspicua; labio interno tenuissimo, rccurvo, cum columclla continuo.

P. shell ovate, thin, shining, pellucid, pale fulvous, or reddish or brownish green, or olive, or horny brown, occasionally pale yellow and almost white; spire short, acuminated; whorls, five, sloping; aperture oblique ; columella white, thin, twisted, pliaits rather conspicuous; inner lip very thin, recurved, and continuous with the columelli. Length from 8 to 13 mill., breadth from $4 \frac{1}{2}$ to $7 \frac{1}{2}$ mill.

This shell which appears to have escaped the notice of previous naturalists is the common Physa of the country, and is found in all the inland streams. It is, however, so closely allied to the Physa fontinalis which is diffused over Great Tritain and Europe that we may well doubt if it be distinct. If not, lias it been introduced? It is very hard to suppose 
this sceing the remote places where it is found. The shell varies much in color aceording to the locality. Specimens from streams near the Great Lalie are reddish, thoso from the Clyde olive, and the Coal River specimens very varied. Five rarieties, with many examples of eael, were furnished me by Mr. Legrand. To judge from the figure alone in Reove's Icon. the species would be taken for $P$. nitida, but the latter is a much smaller shell, with a wider aperture and moro globose habit.

10. Prissa cilitita n.s. P. testa subonata, fusco-comea, longitudinaliter striata, lineis spiralibns, sub-distentibus, ciliatis, cincta; spirabrevi, accuminata, anfiuc. (5) declivis, penultimo influto; apertura subovata, magna; columella alba, plica conspicaed.

P. shell subovate, horny brown, striate lengthwise, girdled with spiral subdistaut ciliated lines; spire short, acuminated; whorls five, sloping, penultimate inflated, aperture subovate, large; colnmella white, plait conspicuous. Length 17 mill., breadth 8 mill.

Habitat, Lake Dulverton, and Bruni Island.

This ciliated form is quite exceptional in the genus, only one other being found in India. That species is, however, cancellate, and of a different color, with an angulated aperture, though in general form not unlike the present species.

11. Physa tasuranicola n.s. P. testa minutissima, ovata, long: striata, luteo-comé, pellucida; spirabrevinscula, anfrac. (4) distinctis, elcclivis, ultimo oblongo; apertura angustiuscula, columella tenui, plica inconspicua, labio interno cum columella continuo, recurvo.

P. shell very small, ovate, longitudinally striate, yellowish horny, pellucid; spire short; whorls four, distinet sloping; last whorl oblong, aperture rather narrow, columella thin, plait inconspicuous, inner lip continuous with the columella and recurved. Length 4, breadth 2 mill.

Habitat, found by the Rev. H. D. Atkinson in a water-hole, Mount Murray, East Coast.

This species is closely allied to $P$. bruniensis but is a stouter shell, more globose, not gibbous at the sutures, and not with the peculiar shining brilliancy of that shell.

12. Physa huonicola, n.s., P. testa pracilis, angnesta, fusiformi, fulere, nitida, intus albula, solidinsenla, spira elongate, anfiractibus $(6)$, obliquis, apicalibus partis, plica columellari obsoleta; labio externo sinuato; labio interno albo, reflero.

P. shell graceful narrow fusiform, fulvous, shining, whitish within, somewhat solid, spire elongated, whorls (6) oblique, apicial ones small, columella fold obsolete; outer lip sinuous, inner lip white, reflexed. Length 15, breadth 5 mill. Proportionate length and width of aperture to whole dimensions, length $6-15$, width $3-5$. 
Habitat, Upper Huon River. A very distinct fusiform species much larger and more solid than $P$. huonensis.

BY'THINIA. Gray. 1821.

Testa turbinùto-coniea subumbilicàta, fulvo-vividì,pellùeida, levigata anfractibus 5-\%, plus minùsve rotumlàtis, epidermidè obseuré corneà inditis ; aperturce pyriformé-ovita, integri.

Shell turbinately conical, subumbilicate, fulvous green, pellucid, smooth; whorls 5 to 7 , more or less rounded; clothed with an obscurely horny epidermis, aperture pyriformly ovate, entire.

It has been generally believed that no Bythinia exists in Australia and Tasmavia, and the shells here described have been classed by some naturalists as Paludestrina, D'Orbigny. This genus was, however, erected for semi-globose solid thick shells with a short obtuse spire, and a callous columella, with which description none of the following would agree. But they do agree with Gray's genus of Bythinia, especially in this that the operculum is partly horny and partly, as far as I have been able to ascertain, calcareous. This feature should, it seems, enhance the importance of the other details in assigning a true position to the shells. It is a fact, however, that we have in the freshwater streams of Tasmania many species of a univalve spiral shelled mollusc so like the Bythinia of Europe, Asia, North Africa, and North America, that I am forced to include them in that genus, and believe that Australia is not an exception to the world wide diffusion of Bythinia. The Tasmanian species are all very small.

1. Bythinia legrand, n. s. B. testa minima, solidiuscula, elongato-conica, epidermide incompleta, obseure olivacea, spira obtusa;

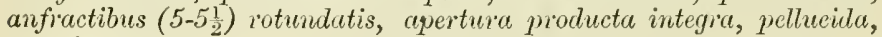
margine acuto.

Shell small, somewhat solid, elongately conical, with an obscurely olive, incomplete epidermis; spire obtuse, whorls ( 5 to $5 \frac{1}{2}$ ) rounded, aperture entire, produced, pellucid, margin acute. Length, 2 ; breadth, 1 mill.

Habitat, Brown's River.

This shell is distinguished by its size, solidity, obtuseness, and few whorls. It retains these characters so constantly under every circumstance that it cannot be regarded as a mere variety.

2. Brthinia pontvillensis, n.s. B. testa turbinato conica, obtusa, pellucida, nitida, fulvo-cornea epirlermidé pallide lutea, anfiactibus, (6) rotundatis, ultimo anfiuctu sub-inflato, apertura ovato, ab ultimo anficactu disjuncta.

Shell turbinately conical, obtuse, pellucid, shining fulvous, horny, with a pale yellow epidermis; whorls (6) rounded, 
last whorl subinflated, apertnre ovate, disjoined from the last whorl. Length, 3 ; breadth, 1 mill.

Habitat, Jordan River, near Brighton. Augustus Simson.

A very distinet but small species, with the whorls sometimes almost entirely separate.

3. Brthinia dulvertonensis, $n$. $s$. B. testa turbinato-conica, fulve, epidermide alba, spira obtusa, anfiactibus (G) rotundatis; apertura ovata, superné angulata, integra, ab anfractu distinctu, intus albida.

Shell turbinately conical, fulvous, with a white epidermis; spire obtuse, whorls (6) rounded, aperture ovate, angulated above, entire, distinet from the whorl, whitish within. Length 3 ; breadth 2 mill.

Habitat, Lake Dulverton. More turbinate than any of tho preceding species. Under the microscope the epidermis is found to cousist of small, oval, silvery scales.

4. Brthisia uuoxessis, $n$. s. B. testa elongata, pyramidata, attenuata, fumoso-cornea, nitida, epidermidé fuscu; spira elcoute acuminata, anfractibus $(S)$ vis obliquis, duobus apicalibus aliquando subinflatis, apertura pyriformi ; labio interno reflexo.

Shell elongate pyramidal, attenuate, smoky horn, shining, with a blackish epidermis; spire elevated, acuminated, whorls (8), scarcely oblique; the two apicial sometimes inflated, aperture pyriform; inner lip reflected. Length 4. Breadth $1 \frac{1}{2}$ mill.

Habitat, Huon River. A very distinct and interesting species, with a pyramidal habit.

5. Bуthinia unicarinata, n. s. B. testa elongato-conica, tenui, semi-pellucida, fumoso-eomea, anfractibus (G) rotundatis, duobus ultimis unicarinatis, carina intermpla; apertura ovata, integra crassiusculu.

Shell elongately conical, thin, semi-peliucid, smoky horn, whorls (6) rounded, two last with one interrupted keel; aperture ovate, centre somewhat thickened. Length 4. Bieadth $1 \frac{1}{2}$ mill.

\section{Salmon Pouds-Not common.}

6. Bythinia dunrominexsis, $n$. s. B. testa elongato-pyrimilata, temi, pelluciula, albidu, epidermidé pallide mufe vel atra maeulata; anfractibus (6) planatis regulariter decrescentibus; spira obtusa; apertura pyrifurmi, integra; labio interno superné reflexo.

Shell elongately pyramidal, thin, pellucid, whitish, spotted with yale or black epidermis; whorls (6) regularly deereasing; spire obtuse, aperture pyriform; inner lip reflected above. Length, 3 ; breadth, 1 mill.

The Ouse near Dunrobin. A pale narrow shell longer and more slender than any of its congeners.

7. Brthisia tasmaxica, n.s. L. testa turbinato-conica, solielius- 
cula, olivacea ; densè squamata, squamis minutissimis, nilidis, ovat is; spiru acuta; anfractibus (G) rotundatis, regnluriter decrescentibus; apertura integra, ovata.

Shell turbinately conical, somewhat solid, olive, thickly covered with very minute shining ovate scales; spire acute; whorls (6) rounded, regularly decreasing, aperture ovate, entire. Length 4 , width 2 mill.

Habitat, creeks throughout Tasmania. In old specimens especially near Hobarton the scales are a good deal hidden by green deposits of confervoid spcres.

\section{POMIATOPSIS. TRYON.}

(Contributions to Conchology. New York, 1862.)

Testa parva tenui, levigata, elongata, subumbilicata; spivaturitu, apertura ovata; labio interno reflexo. Operculum corneum.

Shell small, thin, smooth elongate, sub-umbilicate. Spire turreted. Aperture ovate, inner lip reflectel. Operculum horny.

1. Pomatopsis striatula. Menke (Moll. Nov. Holl. p. 9. Cox. mon. 1862 p. 95. Pl. xv. fig. 13 a.b.c.) P. testa pyramidata (sope truncata), temi, opaca, carneo-alba, intus rufo-fulva; anfiactibus rotundatis, regulariter decrescentibus ; spira obtusa; apcrtura ovata, crassiuscula, integra ; labio interno ab anfiactu ultimo disjuncto.

Shell pyramidal, often truncate, thin, opaque, fleshy white, inside reddish brown, whorls (6) rounded, regularly decreasing, spire obtuse, aperture ovate, somewhat thickened, eutire, inner lip distinct from the last whorl. Length 7, breadth 3 mill.

Habitat, Muddy and Clarence Plains, Rev. H. D. Atkinson. This shell was described as Blanfordia by Dr. Cox, as it was thought to be a land shell, but the Pomiatopsinæ are am. phibious. This specimen is said to be fonnd in South Australia, Victoria, and elsewhere. I believe I have fonnd it in the interior of the continent in freshwater swamps in the Murray deserts, South Eastern district, \&c.

\section{ASSIMINEA. LEACH.}

(A synopsis of Moll. of G. Brit. Lond., 1820.)

Testa pyramide-conice, solidinscula nmbilicata, umbilico parvo st ferè occulto; rnfractilus lavigatis declivis convexis ad basim obtusè angulatis apertura integra, al anfi. ultim. adherenti, columella tenuiter callosa. Operculum cornexm.

Shell pyramidally conical, somewhat solid, umbilicate, umbilicus minute, small and nearly hidden,wlıorls smootl, sloping convex, obtusely angular at tho base, aperture entire, ad- 
hering to the last whorl. Columella thinly callous. Opera culum horny.

Assiminea was first discovered in the Bay of Naples and afterwards in Britain. Səveral allied forms oceur in India and China. There is a globose form in Chili, and the genus appears to be represented by Amnicola in N. America. But as the determination of the genus rests more upon the structure of the animal than the shell, and as the new European species have not been examincd, tho identification must remain doubtful. For the information of observers who may pursue the subject, the following is the description of the animal. Body small; head produced into a ringed muzzle notched in front, tentacles short, united with the cye pedicels and bearing the eye at the summit, foot ample, broad in front, short and rather obtuse behind, carrying a slight horny, few whorled operculum.

1. Assminea tasmavica 2 s. A testa turbinato-conica, para, opaca, pallide viridi, intues fulve ; cpidermidé olivacea (sapè convòsà); spira acuta; anfractibes (5) planatis, cpcrtura fielue.

Shell turbinately conical, small, opaque, pale green, fulvous within with an olive epidermis (often corroded), spire acute, whorls (5) flattened, aperture, columclla, and callosity fulvous. Length 4 , breadth ¿ mill.

Habitat, Sorell, a somewhat solid shell with much the habit of a small Littorina.

\section{PLANORBIS. Guettarn.}

(De Ia Classification des Coq. Paris 1756.)

Testa aliscoidere, spira depressa rix: priminula; anfractibus omnibus ntrinque conspicuis, apertura oblonga, lienatu, ab ace remotissima; murgine numpiam reflexto; operculum nullum.

Shell discoid, compressed, spire scarcely prominent, whorls all visible on both sides. Aperture oblong, remote from the axis, margin never reflected, no operculum.

Freshwater shells of world-wide distribution. The species also have a wide range. Mo*e than 100 are known and the $y$ are very abundant in America. The variations from the typical form are not numerous. There are two or three known in Australia but only one in Tasmania, and this appears to have escaped previous observers.

1. Planoreis tasmanicus n.s. P. discoider, mimuta, planata, tenuis, supcrine convesa, inferne umbilicate, confcrtim sinuato-striuta, nitidn, pelluciula, pallide comea, anfractibus (4-4 busim dilatat is ; sutura mofunda; apertura oveta, obliqua; peristoma simples sinuato. Diam. maj. 5, alt. 1, min. $3 \frac{1}{2}$ mil.

Shell discoidal, minute, flattened, thin, convex above, umbilicate below, thiclily sinuatcly striate, shining pellucid, palc 
horny; whorls 4 to $4 \frac{1}{2}$, convex, dilated at the base, suture deep, aperture ovate, oblique, peristome simple, sinuated. Diam. 5., base $3 \frac{1}{2}$, height 1 mill.

Habitat, still waters throughout the island.

\section{PALUDESTRINA.}

Under the head of this genus Mr. John Brazier, C.M.Z.S., has described the following species (See Proceedings of the Zoological Society of London, for the year 1871, pago 696, "Descriptions of seven new species of Helix, and of two fluviatile shells from Tasmania, by John Brazier, C.MI.Z.S.) :-

Paludestrina iegrandiana.-Shell elongately conical, thin, semi-pellucid, greenish horn color, under a dark epidermis; whorls $6 \frac{1}{2}$, somewhat flattened, the last three keeled between the suture, and furnished with small, solid, stunted hair-like spires, (as seen under the lens) of a bright, transparent horn color, flattened on the top; aperture ovate, margins continuous, thickened, outer lip reflected. Length $2 \frac{1}{2}$ lines. Breadth $1 \frac{1}{4}$ lines. Hab., Salmon Ponds, New Norfolk, Tasmania (Legrand.) This species is allied to Paludestrina Salleana, Fischer from Auckland, New Zealand.

Palddestrina wisemaniana. - Shell elongately conical, thin, semi-diaphanous, epidermis light green; apex acute; whorls 6 to $6 \frac{1}{2}$; convex smooth, grooved at the suture; aperture ovate; margins continuous, moderately thickened, columellar margin reflected, outer lip edged with green and reflected. Length 2 lines. Breadth 1 line. Hab., near Hobart Town, Tasmania, common in all creeks. Legrand and Petterd."

So far Mr. Brazier, but I must add that I have been unable to find either of the above shells nor anything resembling them in Mr. Legrand's extensive collections. I am unable to communicate with Mr. Brazier, as he has sailed for New Guinea in Mr. MrcLeay's expedition. I am obliged, therefore, to conclude that some mistake has occurred in transmitting the specimens. No such shells exist in Tasmania as far as at present known.

\section{BIVALTES. \\ UNIO. Philippsos.}

Usio Moretonicus, Sow. U. testa late ollunga, latere antico declicirotumlato, postico oblique anguluto, deinde oblique truncuto; fusco nigricante.

Shell broadly oblong, anterior side slopingly rounded, posterior obtusely angled, then obliquely truncated; fuscous black. Iength 70 , breadth 41 , height 30 mill.

Tasmania, in the northern rivers, but not in the southern. The name has been applied under the idea that it is found in 
Noreton Bay, Queensland, which is not the ease. It appears that young specimens of Unio cucumoides, which occurs there rery much resemble our spoeies. This is probably the origin of the erroneous habitat in Reeve. It would be rather singular to find a Tasmanian species in a river on the Australiau continent more than 1,400 miles away, aud in no intermediato locility.

\section{PISIDIUMI. PFEIFFER.}

(Systematische Anorduung und Beschreibung Deutscher Land und

Wassersehnecken, ¿e., Cassel et Berlin 1821-28, 3 vols. 40.)

Testa temis aquiralvis, inapuilateralis, anticé producta, epidemiule olivaceo-cornea imlute, concentricé rugosa vel striate, intus albide, umbonibus prominentibus, tumidis, ligamentum subextermun, inconspicuum, latere minore insertum; dentibus eurlinulibus minimis, in utrâque valve duobus divergentibus, in una value binis, subdistantibnes subelongatis; in altera quatuor duobus veré exiguis ; impressionibus muscularibus duobus, lateralibus; impressione pallii sinu nullo.

Shell thin equivalve inequilateral, produced in front, covered with an olive epidermis, concentrically rugose or striate, whitish within, umbones prominent, tumid, ligament subexternal, inconspicuous, inserted in the shorter side, with two small hinge teeth in each valve, one of which is double in one valve, lateral teeth distant and somewhat elongate, muscular impressions two, with no pallial sinus.

This genus was separated from Cyelas on account of the difference of the siphonic tubes, and of the shells which in Pisidium are snaller, with the anterior side the longer, and the ligament on the shorter side.

They are found throughout Europe abundantly, but the foreign species are not well known, though India and New Zealand both possess speeies.

Pisidium tasmaxicum, n.s. P. testa orbiculato-oruta, temuis, ventri$\cos a$, pellucida, albida, regulariter concentricé striata, inquiluteralis, utrinque rotumlata; latere antico subproducto, postico obtuse rotunduto, umbonibus obtusis, ligamentum inconspicuum.

Shell ovate, thin, ventricose, pellucid, whitish, regularly concentrically striate, inequilateral, or rounded on both sides; anterior side subproduced, posterior rounded obtusely, umbones obtuse, ligament inconspicuous. Length from 2 to 4 ; breadth $1 \frac{1}{2}$ to $2 \frac{1}{2}$; height 1 to 2 mill.

Habitat, Brown's River, Great Lake, Lake Dulverton, Dunrobin, and creeks near Hobarton. A small fragile shell in which the epidermis is not easily discovered. The specimens vily in size, and those from the Takes are larger, a little more oblong, with shades of smoky horm, but I have never seen enough divergence of character to warrant the erection of wore than one species. 
Pisinicy neltertonexsis, n.s., P. orata, temuis, rentriensa, rufofulve, nitula, regulariter concentrice striata; inerpiluteralis, lutcre antico producto, subengulato; postice obtuse rotundato et subangulato; umbonibus prominentibus.

Shell ovate, thin, ventricose, fulvous-red, shining, regularly concentrically striate, inequilateral, anterior side produced, subangulate, posterior obtusely rounded and subangulate, umbones prominent. Length 7 ; breadth $5 \frac{1}{2}$; height, $3 \frac{1}{2}$ mill.

This remarkable species is much larger and different in color from the preceding. It is more angular in outline and more oblong. Like all the species from Lake Dulverton it is quite restricted in its habitat.

\section{CYCLAS. Klein. (pars). 1753.}

Testa ut supra (vide descript. Pisid. generis) ligamentum tamen latere majore insertum.

Shell as above in Pisidium, but the ligament is inserted in the longer side.

Crelas tasmarica, n.s. C. testa suhquadrata, ventricosa, temui, nitida, cameo-lutea, intus alba; eleganter striata; sulcis $3 \mathrm{rel}$ it transversis, subcoloratis; umbonibus prominentibus sub-obliquis.

Shell subquadrate, ventricose, thin, shining, fleshy yellow, white inside, elegantly striate, with 3 or 4 silver-like bands of colour which are lines of growth. Umbones prominent, suboblique. Length 9. Breadth $7 \frac{1}{2}$. Height 5 mill.

Habitat, east coast, near Swansea. A very remarkable but somewhat small Cyclas, the only one known in Tasmania. 
The following Valvatia wis found by Mr. Augustus Simson in a small trickling stream in Gould's Country, north-eastern Tasmania. It is the first Valvata known in the island, or in Australia.

Valvata tasmanica. n.s. V.t. minuta,globosé turbinata, profunde lateque umbilicata, pallide comea, epidermide atrato maculata, solidiuscula, semipellucida; unfractibus 4, rotundatis, tenuissime undulosé striatis, ad suturas subeconaliculatis; apertura semilunari, reflexa, postice angulata; labro medio producto, antice subeverso; labio recto tenui; umbilico marginato. Operculum comenm, voale, spirale.

Long. 1. Lat. 1, millimeter.

V. shell minute, globosely turbinate, deeply and widely umbilicate, pale horny, spotted with a blackish epidermis, rather solid, semipellucid, whorls 4, rounded, faintly undulately striate, subcanaliculate at the sutures; aperture semilunate, subreflexed, posteriorly angulate, outer lip produced in the middle, subeverted anteriorly, inner lip straight and thin, umbilicus margined. Operculum horny, oval, and subspiral. 